\title{
ВИКОРИСТАННЯ ЗАСОБІВ ЦИФРОВОГО ОСВІТНЬОГО СЕРЕДОВИЩА ВЧИТЕЛЯМИ IHOЗЕМНИХ МОВ
}

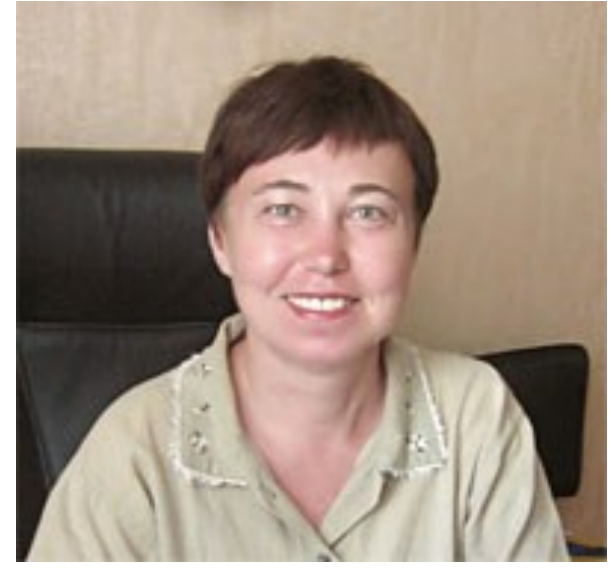

IВАНЮК Ірина Володимирівна кандидат педагогічних наук, старший науковий співробітник відділу компаративістики інформаційно-освітніх інновацій Iнституту інформаційних технологій і засобів навчання Національної академії педагогічних наук України, м. Київ, Україна
Анотація. У статmі розглянуто поняття «цифрове освітне середовище». Звернено увагу, що вчителям іноземних мов при виборі цифрових засобів варто проводити оцінювання їх педагогічної цінності та доцільності. Учителям рекомендовано використовувати перелік принципів навчання іноземних мов, що пропонуються експертною групою з питань мови та педагогіки видавництва Кембриджського університету, а саме принципів: використання різноманітних видів подачі навчального матеріалу; позитивного залучення; індивідуального навчання; зворотного зв'язку; автономного навчання; змістовного спілкування; активного навчання. Наголошено, що такий підхід допоможе прийняти рішення щодо використання певних цифрових засобів і навчальних матеріалів для навчання мов в умовах реформування Нової української школи. Подано приклади цифрових засобів для навчання іноземних мов, що можуть бути використані вчителями для розвитку цифрового освітнього середовища у закладах загальної середньої освіти. Це сприятиме формуванню в учнів іншомовної комунікативної та інформаційно-цифрової компетентності. Проаналізовано такі цифрові засоби: Busuu.com, ChatterPix, NewspaperClub ARTHR, ThingLink, Zoom, VEO. Запропоновано використати їхні можливості учнями та вчителями для проведення уроків іноземних мов. Визначено сильні та слабкі сторони запропонованих цифрових засобів, на які мають звернути увагу вчителі під час підготовки та проведення уроків з іноземних мов. Зроблено висновок, що вчителі іноземних мов можуть під час навчального процесу користуватись не лише традиційними технологіями та методиками проведення уроку, а й цифровими засобами навчання, що будуть корисними та есрективними під час викладання інших шкільних предметів, які сприятимуть водночас формуванню в учнів інформачійно-цифрової та іншомовної комунікативної компетентності учнів. Наголошено на доцільності поєднання різних форм використання цифрових засобів під час проведення уроку та в позаурочній діяльності учнів, що сприяє розвитку аналітичного та критичного мислення, креативності, формуванню дослідницьких навичок, умінню планувати свої дії і спілкуватись.

Ключові слова: цифрове освітнє середовище; інформаційноцифрова компетентність; спілкування іноземними мовами; іншомовна комунікативна компетентність; інформаційнокомунікаційні технології; цифрові засоби.

Сучасний стан розвитку суспільства характеризується істотним впливом інформаційно-комунікаційних технологій (IKT) на всі сфери людської діяльності, зокрема галузі освіти. Основною тенденцією у світі стає модернізація системи освіти, що супроводжується значними змінами у теоретичних і практичних підходах до освітнього процесу в закладах загальної середньої освіти (33СО). При цьому важливо створити відкрите, гнучке та 
широко доступне цифрове освітнє середовище, яке відповідало $б$ сучасним вимогам інформаційного суспільства.

В Україні протягом останніх років здійснено значні кроки щодо формування цифрового освітнього середовища в 33СО. У концепції Нової української школи (НУШ) зазначено, що «організація нового освітнього середовища потребує широкого використання нових ITтехнологій, нових мультимедійних засобів навчання» (МОН України, 2016). ІКТ створюють значний потенціал для рівного доступу до цифрових освітніх середовищ з метою підвищення в учнів навчальних результатів і мотивації до навчання. Останніми роками відбувається дискусія щодо створення Національної платформи цифрової освіти в рамках реформи НУШ, що покликана бути рушієм істотних змін в освітньому процесі та започаткувати ринок виробництва електронних освітніх продуктів і сервісів в Україні. Однак, на жаль, ця платформа досі не створена.

Під час упровадження сучасної вітчизняної освітньої реформи одним із важливих напрямів роботи стало формування в учнів компетентностей інформаційно-цифрової та спілкування іноземними мовами (іншомовної комунікативної компетентності), що включені до списку 10-ти ключових компетентностей НУШ (МОН України, 2016). Учителям іноземних мов важливо мати уявлення як про нові навчальні ІКТ і мультимедіа, так і про цифрові засоби, що допоможуть їм досягти поставлених навчальних завдань. 3 огляду на те, що таких інструментів створено багато, перед учителем постає питання, як відібрати 3 них найбільш ефективні для своєї роботи у класі, чи варто використовувати лише спеціально створені інструменти, спрямовані на вивчення мов, чи можна використати можливості інших цифрових ресурсів широкого профілю?

Важливо враховувати міжнародно визнані стандарти й документи, що окреслюють орієнтири вивчення мов сьогодні. Такими орієнтирами $є$ :

- загальноєвропейські рекомендації з мовної освіти: вивчення, викладання, оцінювання (Council of Europe, 2001). Цей документ був опублікований у 2001 р. (Європейський рік мов) після пілотування і низки консультацій, що проводилися Радою Європи у Страсбурзі, та доступний 40 мовами, є одним із найвідоміших і найбільш використовуваних інструментів політики Ради Європи та предметом рекомендацій Комітету Міністрів і Парламентської асамблеї. Європейська комісія також його прийняла, включаючи їхній проєкт EUROPASS і проєкт встановлення європейського показника мовної компетентності. Цей документ покликаний подолати бар'єри для комунікації серед професіоналів (зокрема вчителів), які працюють у галузі сучасних мов, що виникають у різних освітніх системах країн Європи. Рамка надає засоби для розробників курсів, викладачів закладів вищої освіти, учителів, щоб здійснювати навчання, що відповідає реальним потребам учнів, за яких вони несуть відповідальність.

- Загальноєвропейські рекомендації з мовної освіти: вивчення, викладання, оцінювання, decкpunmopu (Council of Europe, 2018). Ця публікація - ще один крок у процесі, що здійснює Рада Європи разом з учителями та викладачами мов по всій Європі та за ії межами. Завдання документа - уточнити основні дескриптори мовної компетентності та пов'язати між собою освітні стандарти, методичні підходи та зміст щодо вивчення мов у сучасному багатомовному світі. Особливу увагу цей документ приділяє використанню аудіо-візуальної активності учня (перегляд ТВ передач, відео та ін.), онлайнспілкуванню та веденню дискусії, що сьогодні безпосередньо пов'язано з цифровим засобами та засобами масової інформації. До них, зокрема, відносяться онлайн-розмова та дискусія в Інтернеті як мультимодальному явищі, з акцентом на тому, як співбесідники спілкуються в Інтернеті для вирішення серйозних питань і соціального обміну відкритим способом. Основні поняття, що відносяться до онлайн-спілкування:

- обставини одночасної (в реальному часі) та послідовної взаємодії;

- участь у постійній взаємодії з одним або кількома співрозмовниками;

- складання постів і участь інших осіб;

- коментарі (наприклад, оцінювання) щодо публікацій, коментарів і долучення інших осіб;

- реакції на засоби масової інформації;

- можливість включати символи, зображення та інші коди, щоб повідомлення передало тон, стрес, а також афективну/емоційну складову спілкування, іронію тощо (Council of Europe, 2018).

Методи дослідження полягають у виокремленні та аналізі зарубіжного досвіду використання цифрових засобів для навчання іноземних мов, пошуку ефективних шляхів, принципів та ідей, які можуть бути адаптовані у національну 
систему освіти та матимуть практичне значення для сучасної освітньої реформи.

У галузі використання ІКТ в освітньому процесі накопичено значний науковий потенціал, який відображено в роботах сучасних вітчизняних вчених В.Ю. Бикова, О.Ю. Бурова, В.П. Беспалька, А.М. Гуржія, М.І. Жалдака, Ю.О. Жука, Т.І. Коваль, В.В. Лапінського, А.Ф.Манако, Н.В.Морзе, Е.І. Машбиця, О.О. Олійника, О.В. Співаковського, С.О. Семерікова, О.М. Спіріна, Ю.В. Триуса та ін.

Теоретичні основи створення та впровадження цифрового освітнього середовища досліджуються у роботах В.Ю. Бикова, М.І.Жалдака, Ю.О. Жука, К.Р. Колос, В.В. Лапінського, Н.В. Морзе, О.В. Овчарук, О.П. Пінчук, І.В. Пліш, Н.В. Сороко, Ю.В. Триуса та ін.

Практичне використання засобів цифрового освітнього середовища під час викладання навчальних предметів у З3СО розглядається у роботах зарубіжних вчених Д. Кідд, Д. МакКінлея, Р. Паттона, Р. Сантоса, С. Шіна, М. Шихана та ін.

У педагогічній літературі поняття «цифрове освітнє середовище» трактується по-різному, а саме: «комп'ютерне середовище», «комп'ютерно орієнтоване середовище», «комп'ютерно орієнтована методична система навчання», «комп'ютерне навчально-розвивальне середовище», «відкрите освітнє середовище», «віртуальне освітнє середовище», «інформаційно-освітне середовище» та ін. Усі ці поняття мають певні відмінності й розглядаються дослідниками щодо різноманітних освітніх цілей.

В.Ю. Биков розглядає освітнє середовище закладу освіти як «штучно і цілеспрямовано побудований простір, в якому розгортається навчальний процес і в якому створені необхідні та достатні умови для його учасників щодо ефективного досягнення цілей навчання і виховання» (Биков, 2008).

Ю.О. Жук звужує поняття і визначає його як середовище, у якому забезпечуються умови інформаційної взаємодії в процесі навчання певного навчального предмета (предметів) між учителем, учнем і засобами навчання, що функціонують на базі засобів IKT (Жук, 2012).

У концепції НУШ формула нової школи включає в себе дев'ять компонентів, одним із яких визначено "сучасне освітнє середовище, яке забезпечить необхідні умови, засоби і технології для навчання учнів, освітян, батьків не лише в приміщенні навчального закладу» (МОH України, 2016).
Ми погоджуємось з підходами згаданих авторів до трактування поняття освітнього середовища та вважаємо, що комп'ютерні засоби та сучасні технології дають змогу учасникам освітнього процесу створювати технологічно нові форми спілкування іноземними мовами, застосовувати засоби навчання, не обмежуючись простором освітнього закладу. У своїй роботі ми застосовуємо термін «цифрове освітнє середовище». Під цифровим освітнім середовищем у контексті вивчення іноземних мов ми розуміємо сукупність засобів, ресурсів і сервісів інформаційнокомунікаційних мереж, що забезпечують спілкування, взаємодію, навчання та підтримку вивчення іноземних мов, участь у віртуальних навчальних спільнотах для формування в учнів іншомовної комунікативної компетентності. Іншомовну комунікативну компетентність слід розглядати як інтегративну якість особистості, комплекс знань, умінь і навичок використання та спілкування іноземною мовою.

Метою і завданням статті $€$ огляд та аналіз низки цифрових засобів і ресурсів цифрового освітнього середовища 33СО, що використовують учителі іноземних мов зарубіжжя для розвитку і формування в учнів іншомовної комунікативної та інформаційно-цифрової компетентностей, надання пропозицій вітчизняним фахівцям.

Цифрові засоби надають учителям іноземної мови додаткові можливості для викладання навчального предмета, окрім тих, що пропонують паперові підручники. Вчителю важливо розуміти, що вони собою являють та як їх можна застосовувати під час роботи з учнями. Варто проводити оцінювання педагогічної цінності цифрових засобів, щоб з'ясувати, як вони відповідають принципам вивчення іноземних мов і поставленим учителем навчальним завданням.

у країнах зарубіжжя учителі іноземних мов широко використовують цифрові засоби для роботи в класі, зокрема для навчання іноземним мовам. Серед особливостей використовуваних ресурсів і засобів увага приділяється тим, що спряють активному спілкуванню учнів з носіями мов, між однолітками, з учителем відповідно до поставлених навчальних цілей. Акцент у використанні цифрових засобів і ресурсів переважно спрямований на керування взаємодією спілкування, формування в учнів культури мовлення, готовності до різних форм взаємодії іноземною мовою. 
Серед розробників підходів і принципів до навчання іноземних мов слід виділити дослідників Кембриджського університету у Великій Британії, зокрема Д. Кідд, експертку з питань мови та педагогіки. Дослідниця розробила та запропонувала використовувати низку принципів щодо оцінки й відбору цифрових засобів та інструментів навчального середовища для вивчення іноземних мов відповідно до поставлених навчальних завдань:

- принцип використання різноманітних видів подачі навчального матеріалу. Чи підходить цей інструмент для насиченого, релевантного, змістовного розуміння мови учнями? Наприклад, зображені інструменти допомагають контекстуалізувати мову, представляючи ії мультимедійними засобами (візуалізація, аудіо, відео), роблячи ії більш зрозумілою для учнів;

- принцип позитивного залучення. Чи залучає цей інструмент учнів до навчання, мотивує і ставить перед ними виклики? Наприклад, онлайнігри допомагають зовнішній мотивації за використання табло з балами, рейтингами та спонукаючи учнів знову повертатися до них, щоб продовжувати навчатись;

- принцип індивідуального навчання. Чи дає інструмент можливість враховувати індивідуальні потреби учня? Наприклад, робочі онлайн-зошити можуть забезпечити ступеневий навчальний контент для учнів, який відображає їхні індивідуальні потреби;

- nринцип зворотного зв'язку. Чи надає інструмент детальний зворотний зв'язок учням? Наприклад, під час виконання завдань у цифровому форматі інструмент дає змогу отримати миттєвий зворотний зв'язок, тому учні можуть зразу бачать, коли вони помилилися, мають шанс спробувати виконати завдання ще раз та виправити помилку;

- принцип автономного навчання. Чи дає інструмент учням можливість брати на себе відповідальність за власне навчання? Наприклад, онлайн-платформи можуть забезпечити окреме місце для учнів, щоб вести облік роботи та спостерігати за власним прогресом у часі, тобто створювати власне портфоліо успіху;

- принцип змістовного спілкування. Чи дає інструмент учням можливість використовувати мову або запропонований учителем контекст змістовно? Наприклад, інструменти співпраці дають учням можливість спілкуватися з однолітками та іншими учнями незалежно від часу та місцезнаходження;
- принцип активного навчання. Чи спонукає інструмент учнів до творчого та різноманітного навчання? Наприклад, такі інструменти, як аудіота відеопристрої дають учням змогу виявляти творчість за допомогою різних технічних режимів і засобів (Kidd, 2019).

Слід наголосити, що такі принципи вивчення іноземних мов з допомогою цифрових засобів осучаснюють процес навчання, спонукають учителів застосовувати новітні інструменти, оцінювати їхню ефективність і приймати рішення щодо доцільності використання у практичній роботі. Для учителів іноземних умов важливо, щоб учні демонстрували прогрес у таких основних навичках: читання, письмо, аудіювання та говоріння. Тому всі навчальні заходи мають бути організовані так, щоб допомогти учням виявляти ці навички та навчитись працювати зі словниками, покращувати свою вимову та граматику, спілкуватись на достатньому рівні іноземною мовою. Водночас учні проявляють свої комунікаційні навички у віртуальних спільнотах, мережах, спілкуючись 3 однолітками поза шкільним часом. Саме тому доцільне використання вчителями іноземних мов цифрових засобів для навчання сприятиме формуванню комунікаційних навичок.

У дослідженні проаналізовано низку цифрових засобів, що можуть використовуватись для викладання іноземних мов у 33СО. Слід враховувати їхні сильні («плюси») та слабкі («мінуси») сторони при здійсненні різних видів навчальної діяльності та позакласної активності. Отже, цифрові засоби, що можуть бути корисними для учителів іноземних мов.

Thinglink (https://www.thinglink.com/) - це сервіс, що дає змогу створювати мультимедійні картинки, на які наносяться маркери. При наведенні на них з'являється мультимедійний контент.

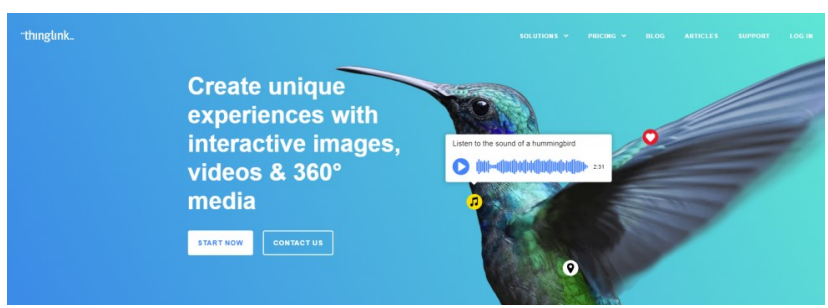

Для учнів: пропонує багато варіантів проявити свою творчість; надає можливість відчути та побачити свої справжні досягнення, наприклад, створити онлайн-портфоліо через розробку серії зображень (картинок) або відео; надає можливість використовувати зображення та відео як банк словникового запасу, орієнтованого на певні теми. 
Для учителів: добре поєднується з певними напрямами викладання мови, зокрема, розвитком словникового запасу та вивченням тематичної лексики; є можливість створити власні навчальні зображення чи відео з контекстом, який буде сильно відрізнятись від звичайного навчального контенту, що зазвичай використовують у школі, саме це стане мотивацією для навчання учнів будь-якого віку; з сервісом добре працювати в аудиторіях із проектором та/або інтерактивною дошкою.

Ідеї для уроків: має великий потенціал як засіб для презентації, можна розкривати теми уроків або розглядати конкретні ситуації з максимальною деталізацією; підходить для створення цікавих та інтерактивних історій або словника для молодших школярів; може допомогти викладанню певної теми за допомогою ії «візуальної прив'язки» (теги, створені на зображенні, можуть діяти як «візуальні якорі»).

Плюси: безкоштовний базовий рахунок для учителя; після реєстрації легко користуватися інструментами створення та редагування, бо вони містять візуальні підказки; працює онлайнпідтримка, яка пропонує як технічну допомогу, так і практичні ідеї щодо використання інструменту.

Мінуси: реєстрація і вибір плану роботи можуть бути трохи заплутаними (але $\epsilon$ онлайнпідтримка); деякі посилання (теги), які користувачі можуть додати, щоб розмістити свій власний оригінальний вміст, пов'язані із сайтами, що потребують реєстрації (наприклад, мережі «Фейсбук», «Інстаграм», «Вімео», «Ютуб»). Для учителів початкової школи це може бути складно, бо учні цього віку не мають права реєструватись на цих сайтах.

Zoom (https://zoom.us/) - це сервіс відеоконференцзв'язку з обміном повідомленнями та передачею контенту в режимі реального часу.

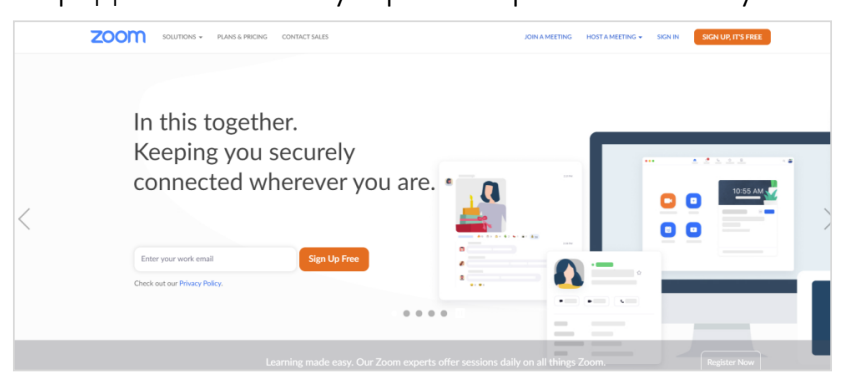

Для учнів: дає змогу легко приєднатися до онлайн-уроку через натискання на URL-адресу, не вимагає облікового запису; підходить для соціальної взаємодії з іншими учнями; дозволяє вчитися у власному темпі та оцінювати свої нави- чки, переглядаючи записані уроки; дає змогу вмикати чи вимикати запис у будь-який момент під час уроку, якщо вчитель дозволяє.

Для учителів: можливість легко записувати свої уроки або попросити учнів зробити це; контроль за збереженням інформаційних даних протягом уроків для поточного та підсумкового оцінювання; дієвий інструмент для групових занять, бо має опцію «розбивка кімнати» для створення маленьких груп.

деї для уроків: надсилання домашнього завдання через відео та аудіо; використання презентаційних засобів чи електронних книг; надсилання учням відео без звуку і завдання описати те, що там відбувається.

Плюси: проста у використанні панель управління та навігація; широкий спектр функцій інструментів для запису; базові рахунки безкоштовні; учасникам не потрібно мати обліковий запис, щоб приєднатися; цілодобова онлайн-підтримка.

Мінуси: потрібен гарний інтернет-зв'язок, щоб використовувати функції аудіо/відео; безкоштовний (базовий) пакет дозволяє проводити уроки тривалістю тільки до 40 хвилин.

Chatterpix (http://www.duckduckmoose.com/ educational-iphone-itouch-apps-for-kids/chatterpix/) це сервіс для створення презентацій з озвучуванням створених картинок і відео.

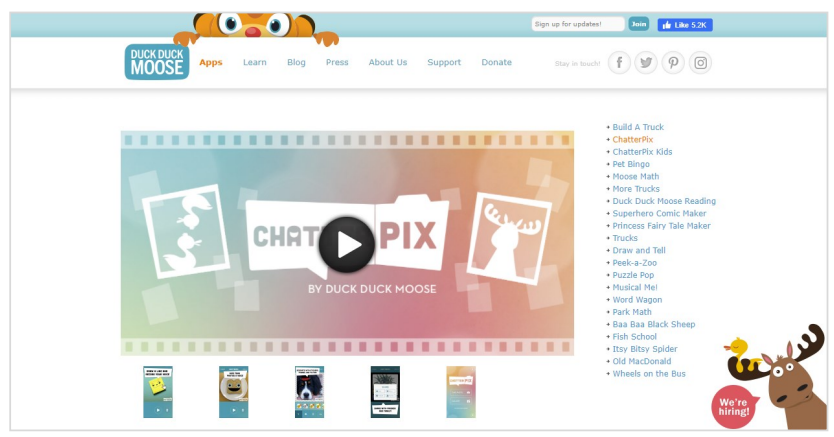

Для учнів: сприяє творчому самовираженню іноземною мовою, яку вивчає учень; дає змогу здійснити самооцінювання та отримати оцінку від ровесника; знижує рівень тривожності у мовних завданнях; включає використання технології у вивчення мови.

Для учителів: безпечний і простий у користуванні інструмент; дає змогу використати відео, щоб створити контент і представити нову тему або дати усні вказівки/короткі пояснення/ персоналізовані відгуки про роботу учнів; дозволяє оцінювати всіх учнів у групі.

Ідеї для уроків: можливість виконання вправи «Криголам» у новій групі під час знайомства, 
запропонувавши учням описати себе за 30 секунд у вигляді створеної презентації; «оживити» знайомого персонажа з навчальної книги або улюбленого дітьми фільму, зробити його поведінку несподіваною, змінивши голос або висловивши їм дивну думку; провести уроки дебатів і запропонувати учням представити свої висновки у вигляді відеоролика, вони можуть використовувати власну картинку або зображення персонажу, який їм подобається.

Плюси: простий у використанні; привабливий інтерфейс; підходить для усіх рівнів вивчення мови та вікових категорій; сприяє залученню до мовленнєвої активності всіх учнів у класі; надає додатковий контекст для мовленнєвої практики; універсальний спосіб покращити зміст уроку та зробити навчання цікавим.

Мінуси: додаток наразі доступний лише на iOS, тому в ідеалі кожному учням потрібен власний пристрій; учні можуть читати вголос, щоб робити свої записи, що негативно впливатиме на вимову і не розвиватиме навички спонтанного мовлення; записи обмежені 30-ма секундами; фоновий шум може ускладнити запис у класі.

Busuu.com (https://www.busuu.com/) - це віртуальна навчальна спільнота для вивчення іноземних мов.

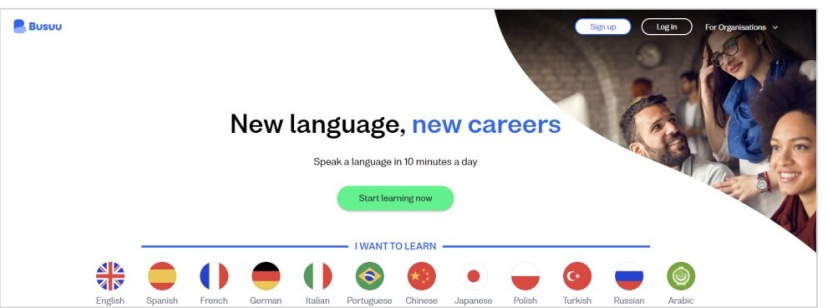

Для учнів: навчання у носіїв мови, що відбувається за допомогою відеочату; практика мовних навичок під час живого спілкування з людьми, які мешкають у різних країнах світу; можливість відстежувати свій прогрес щотижня; можливість відчути себе у ролі вчителя, бо учасники навчальної спільноти виступають водночас у ролі учня та вчителя, перевіряючи виконані письмові завдання інших учасників, які вивчають їх рідну мову.

Для вчителів: інтерактивний навчальний матеріал; розроблено більше 1000 уроків на різні тематики, зміст уроків супроводжується фото- та аудіоматеріалами, можна прослуховувати ключові слова, вирази та діалоги, озвучені професійними дикторами - носіями мови; платформа управління для відстеження прогресу учнів.

Ідеї для уроків: можливість використовувати запропонований Busuu.com матеріал за певними темами на уроках.
Плюси: курси рівнів A1, A2, B1 и В2 на основі Загальної європейської рамки володіння мовами; офіційна сертифікація рівня мови від McGraw-Hill Education; доступно в Інтернеті та мобільному телефоні; навчання у будь-який час і в будь-якому місці в режимі офлайн; легкий у налаштуванні; існують спеціальні курси для закладів освіти.

Мінуси: безкоштовний (базовий) пакет дає змогу використовувати лише матеріали для вивчення нових слів у контексті. Всі інші матеріали містяться у платних пакетах «Преміум» та «Преміум плюс».

VEO (https://veo.co.uk/) - це відеоплатформа для учителів та учнів, яка дає змогу працювати індивідуально та спільно.

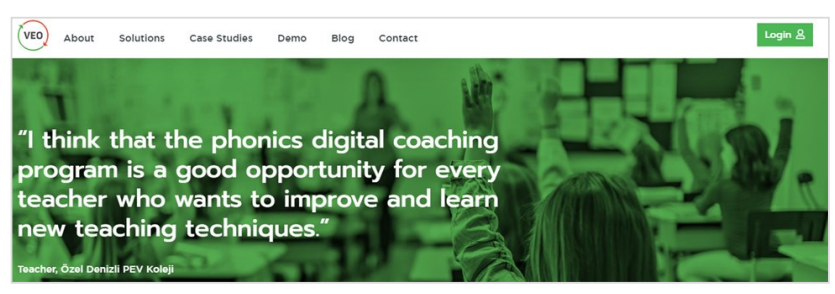

Для учнів: дає можливість відстежувати власний прогрес і визначати сфери, над якими потрібно працювати; ділитися відеороликами, які створили діти та оцінювати роботу однокласників; надає доступ до якісних практичних прикладів, які допомагають визначити для себе певні стандарти виконання роботи; дозволяє отримувати відгуки та оцінки від учителів.

Для вчителів: робить більш продуктивним огляд проведеного уроку; дозволяє легко збирати прямі відгуки від учнів, коли вони працюють на уроці; надає можливість переглянути власну роботу та об'єктивно визначити сильні та слабкі сторони, що потрібно розвивати; дає можливість поширити досвід власних напрацювань між іншими вчителями.

Ідеї для уроків: можна провести уроки дебатів, щоб потім зробити спільний перегляд і рефлексію з учнями; продовжити навчання за межами аудиторії, якщо учні підтримують контакт, завантажуючи відео, додаючи теги та коментуючи роботу своїх однокласників.

Плюси: використання тегів; зрозумілий для налаштування сервіс і відмінний рівень технічної підтримки та обслуговування клієнтів; наявність кількісних (відео) та якісних (теги) даних.

Мінуси: додаток доступний лише на iOS; версія для Android у стані розробки; для використання усього потенціалу VEO необхідне членство закладу освіти. 
Newspaperclub ARTHR (https://arthr.newspaper club.com/) - це засіб для створення безкоштовної професійної онлайн-газети.

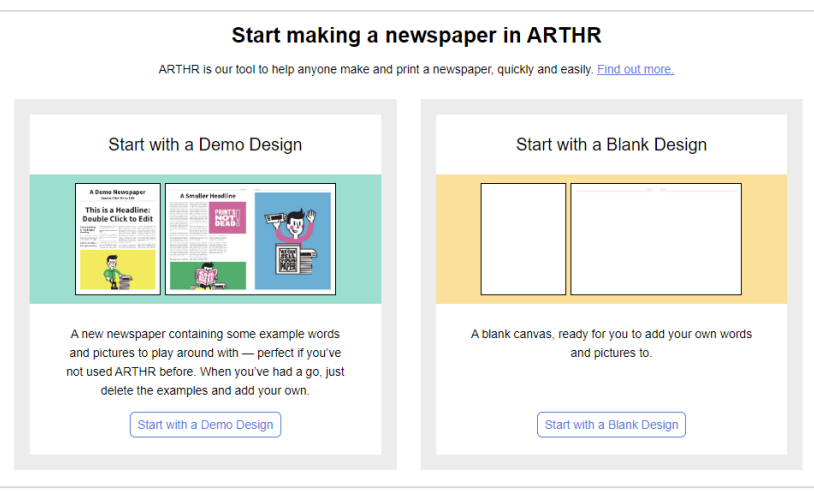

Для учнів: дає змогу практикувати цифрові навички; спонукає створювати та презентувати свої письмові роботи творчо, привабливо та професійно; розвиває мовні, комунікаційні та соціальні навички шляхом спільної роботи.

Для вчителів: дає змогу допомогти учням створити письмовий продукт, яким вони пишатимуться; роздрукувати та демонструвати широкому загалу освітньої спільноти письмову форму роботи учнів; підходить для роботи над проєктами або на уроках за темою; допомагає створити власне професійне портфоліо.

Ідеї для уроків: під час роботи з учнями початкової та середньої школи буде доцільно використовувати інструмент для обробки текстів, а потім додавати їх у газету; можна організувати роботу учнів у невеликих групах; учням старшої школи запропонувати працювати з текстами, використовуючи теми з блогів, які вони ведуть самі.

Плюси: залучення та мотивація учнів; безкоштовне програмне забезпечення для створення онлайн-газети; безкоштовні файли для завантажування з друкованими версіями сторінок газет; ефективна, безкоштовна технічна підтримка клієнтів.

Мінуси: додавання тексту до ARTHR потребує практики, можливо, простіше створити текст у Microsoft Word aбо GoogleDocs, а потім завантажити.

Варто наголосити, що поєднання різних форм використання цифрових засобів під час проведення уроку та в позаурочній діяльності учнів сприятиме розвитку аналітичного та критичного мислення, креативності, формуванню дослідницьких навичок, умінню планувати свої дії, створити власне професійне портфоліо, спонукає створювати та презентувати письмові роботи творчо, привабливо та професійно, безпечно спілкуватися у спільнотах, захищати персональні дані. На жаль, учителі іноземних мов не досить ефективно використовують цифрові засоби, натомість більше уваги приділяють традиційним формам навчання: написання есе, роботі зі словником, 3 посібником, веденню діалогу, аудіюванню в реальному часі, дискусіям. Досвід учителів Великої Британії дає змогу поглянути на процес іноземних мов щодо його осучаснення, активізації та наповнення новими методиками й ідеями, що будуть цікавими для учнів.

Зокрема, такі організації як Рада Європи, Європейський Союз, ЮНЕСКО рекомендують використовувати ці цифрові засоби, щоб сприяти розвитку ключових компетентностей учнів (Ovcharuk, Ivaniuk, Soroko, Gritsenchuk \& Kravchyna, 2020).

Слід зазначити, що у зв'язку з ситуацією, що склалася в Україні 3 оголошеним карантином COVID-19 і необхідністю здійснювати дистанційне навчання, з'ясувалося, що в школах учителі почали широко використовувати різноманітні цифрові засоби: Viber - 88,2\%; сайт закладу освіти 62,7\%; Google Classroom - 45,5\%; На урок 42,7\%; Skype - 37,7\%; Zoom - 28,5\%; Telegram 20,9\%. Підтвердженням цього $є$ аналітичні матеріали результатів онлайн-опитування щодо потреб учителів у підвищенні фахового рівня з пи тань використання цифрових засобів та IKT в умовах карантину (Іванюк \& Овчарук, 2020).

На основі результатів проведеного дослідження слід виокремити рекомендації щодо застосування цифрових засобів учителями іноземних мов у процесі навчання:

1. Учителям іноземних мов перш за все варто провести оцінку педагогічної доцільності застосування цифрових засобів на основі запропонованих вище принципів: враховують різноманітність видів подачі навчального матеріалу, позитивне залучення, індивідуальний підхід, зворотний зв'язок, автономність і змістовність навчання, можливість проявляти творчість. Такий підхід допоможе вчителям прийняти рішення щодо застосування цифрових засобів і навчальних матеріалів відповідно до необхідності формування в учнів таких навичок: читання, письмо, аудіювання і говоріння.

2. Учителям варто звернути увагу на такі цифрові засоби та існуючі професійні спільноти, що розширюють їх можливості та підсилюють процес вивчення іноземних мов:

- Englishforums (https://www.englishforums.com/); 
- Busuu.com (https://www.busuu.com/);

- Livemocha (https://www.livemochas.com/);

- LinguaLeo (https://lingualeo.com/);

- Myngle (https://www.myngle.com/) та ін.

Всі ці ресурси відіграють значну роль у перетворенні процесу вивчення іноземних мов із традиційного академічного на інтерактивний і компетентнісно спрямований. Звертаємо увагу на те, що проведений аналіз ресурсів і засобів для вивчення іноземних мов засвідчує, що вчителі іноземних мов можуть також користуватись й іншими цифровими інструментами, які $є$ цікавими та корисними під час вивчення багатьох предметів. Таке поєднання водночас сприятиме формуванню іншомовної комунікативної компетентності та посилить формування інформаційнокомунікаційної компетентності учнів.

3. Враховуючи міжнародні стандарти та вимоги вітчизняної освіти, вчителям іноземних мов варто інтегрувати цифрові засоби та інструменти. Це спонукатиме учнів до ефективного та критичного застосування цифрових засобів, що допомагають учням індивідуально та спільно виконувати різні види діяльності: здійснювати швидкий пошук необхідної інформації, аналізувати, робити свій вибір; обробляти інформаційні дані, редагувати та створювати новий цифровий контент, безпечно поводитись у цифровому просторі, ділитись своїм досвідом з іншими.

4. Для вчителів особливо важливий обмін досвідом $з$ іншими та поширення найкращих практик викладання іноземних мов. Саме тому участь у цифрових професійних спільнотах $\epsilon$ гарним ресурсом для підвищення обізнаності та обміну думками щодо викладання мов, мотиваційним фактором для учителя. При цьому вчитель має усвідомлювати, що для учня спілкування у цифрових спільнотах сьогодні $є$ нормою. Тому вчитель повинен усвідомлювати, що учні, спілкуючись у спільнотах, розвивають критичне мислення, проявляють креативність, оволодівають навичками дослідника, навчаються планувати свої дії та керувати змінами, вирішувати складні ситуації, розвивати самооцінку.

5. Усвідомлюючи необхідність урізноманітнення процесу викладання іноземних мов, учитель має застосовувати такі форми та методи навчання, що надають змогу повноцінно використовувати цифрові засоби, а саме: проводити вебінари, здійснювати онлайн-проєкти за темами, онлайндебати та ін.
6. На курсах підвищення кваліфікації учителі мають отримати знання та практичні навички щодо використання онлайн-інструментів для дистанційного навчання, організації групової роботи, відеоконференцій.

7. Проведене дослідження не вичерпує розв'язання усього спектру проблем, пов'язаного 3 використанням цифрових засобів і ресурсів освітнього середовища вчителями іноземних мов. Продовжити науковий пошук важливо в таких напрямах: створення інформаційно-освітніх середовищ для вивчення іноземних мов, інтегрування тематик, пов'язаних із вивченням мов, IKT та інших освітніх галузей; розроблення методик для підготовки та підвищення кваліфікації учителів іноземної мови щодо формування в учнів полікультурної компетентності в умовах розвитку цифрового освітнього середовища, розроблення та використання дистанційних методик вивчення іноземних мов засобами IKT.

\section{СПИСОК ВИКОРИСТАНИХ ДЖЕРЕЛ}

Биков, В.Ю. (2008). Моделі організачійних систем відкритої освіти : монографія. Київ: Атіка.

Жук, Ю.О. (2012). Особистісний простір учня в комп'ютерно-орієнтованому навчальному середовищі. Інформаційні технології і засоби навчання, 29(3). https://doi.org/10.33407/itlt.v29i3.693

Іванюк, І.В., \& Овчарук, О.В. (2020). Результати онлайн опитування «Потреби учителів у підвищенні фахового рівня з питань використання цифрових засобів та IКT в умовах карантину». Вісник Начіональної академії педагогічних наук України, 2(1). https:// doi.org/10.37472/2707-305X-2020-2-1-7-1

Міністерство освіти і науки України. (2016). Нова українська школа. Концептуальні засади реформування середньої школи. https://mon.gov.ua/storage/ app/media/zagalna\%20serednya/nova-ukrainskashkola-compressed.pdf

Council of Europe. (2001). Common European Framework of Reference for Languages: Learning, Teaching, Assessment. Cambridge University Press. https:// cutt.ly/tf6upHB

Council of Europe. (2018). Common European Framework of Reference for Languages: Learning, teaching, assessment. Companion volume with new descriptors. https://cutt.ly/sf6uzJ4

Kidd, D. (2019, 29 October). How to select the right digital materials for your students. Cambridge University Press. https://www.cambridge.org/elt/blog/2019/10/29/ how-select-right-digital-materials-your-students/

Ovcharuk, O., Ivaniuk, I., Soroko, N., Gritsenchuk, O., \& Kravchyna, O. (2020). The use of digital learning tools in the teachers' professional activities to ensure sustainable development and democratization of education in European countries. E3S Web of Conferences, 166. https://doi.org/10.1051/e3sconf/202016610019 


\title{
USE OF DIGITAL LEARNING ENVIRONMENT ONLINE TOOLS BY TEACHERS OF FOREIGN LANGUAGES
}

\author{
Iryna Ivaniuk \\ PhD in Pedagogy, Senior Research Fellow of the Comparative Studies Department for Information and \\ Educational Innovations, Institute of Information Technologies and Learning Tools of the National \\ Academy of Educational Sciences of Ukraine, Kyiv, Ukraine
}

\begin{abstract}
The article considers the definition of a "digital educational environment". It is noted that when choosing and using the online tools, a foreign language teacher should evaluate the pedagogical value of digital online tools in order to find out how they comply with the principles of foreign language learning. Teachers are encouraged to use a list of foreign language learning principles offered by Cambridge University's Language and Pedagogics team, such as the principle of using a variety of teaching materials; the principle of positive involvement; the principle of individual learning; the principle of available feedback; the principle of autonomous learning; the principle of meaningful communication; the principle of active learning. It is emphasized that this approach will allow deciding on the use of certain online tools and teaching materials during the educational process. An overview of a number of online tools that can be used by a foreign language teacher to develop the digital educational environment of secondary schools, the formation of foreign language communication skills and information, and digital competence, is made. The online tools of Busuu.com, ChatterPix, NewspaperClub ARTHR, ThingLink, Zoom, VEO are analyzed, considering their use for students and teachers, offering teachers some ideas for using tools during the lessons, identifying the strengths and weaknesses of using online tools by the teacher. It is concluded that, during the educational process, foreign language teachers can use not only specialized tools but also other digital tools that will be useful and effective in many subjects and will help to develop not only competence in communication in foreign languages but also information and communication skills of the students. Foreign language teachers will use communication tools to work collaboratively with the students through digital technology. This will allow students to better: seek, understand, select, process, edit and create new content; demonstrate creativity, critical thinking, and research skills; manage changes and handle complex situations; to develop self-esteem.

Keywords: digital educational environment; digital competence; communication in foreign languages; foreign language competence; information and communication technologies; online tools.
\end{abstract}

Дата публікації: 30 вересня 2020 р. 